\title{
Heat degradation of eukaryotic and bacterial DNA: an experimental model for paleomicrobiology
}

Tung Nguyen-Hieu', Gérard Aboudharam ${ }^{1}$ and Michel Drancourt ${ }^{1,2^{*}}$

\begin{abstract}
Background: Theoretical models suggest that DNA degradation would sharply limit the PCR-based detection of both eukaryotic and prokaryotic DNA within ancient specimens. However, the relative extent of decay of eukaryote and prokaryote DNA over time is a matter of debate. In this study, the murine macrophage cell line J774, alone or infected with Mycobacterium smegmatis bacteria, were killed after exposure to $90^{\circ} \mathrm{C}$ dry heat for intervals ranging from 1 to $48 \mathrm{~h}$ in order to compare eukaryotic cells, extracellular bacteria and intracellular bacteria. The sizes of the resulting mycobacterial rpoB and murine rpb2 homologous gene fragments were then determined by real-time PCR and fluorescent probing.

Findings: The cycle threshold (Ct) values of PCR-amplified DNA fragments from $J 774$ cells and the M. smegmatis negative controls (without heat exposure) varied from 26-33 for the J774 rpb2 gene fragments and from 24-29 for M. smegmatis rpoB fragments. After $90^{\circ} \mathrm{C}$ dry heat incubation for up to $48 \mathrm{~h}$, the Ct values of test samples increased relative to those of the controls for each amplicon size. For each dry heat exposure time, the Ct values of the 146-149-bp fragments were lower than those of 746-747-bp fragments. During the 4- to 24-h dry heat incubation, the non-infected $\mathbf{J 7 7 4}$ cell DNA was degraded into 597-bp rpb2 fragments. After 48 h, however, only 450-bp rpb2 fragments of both non-infected and infected $\mathbf{J 7 7 4}$ cells could be amplified. In contrast, the 746-bp rpoB fragments of $M$. smegmatis DNA could be amplified after the 48-h dry heat exposure in all experiments. Infected and non-infected $\mathbf{J 7 7 4}$ cell DNA was degraded more rapidly than M. smegmatis DNA after dry heat exposure (ANOVA test, $\mathrm{p}<0.05)$.

Conclusion: In this study, mycobacterial DNA was more resistant to dry-heat stress than eukaryotic DNA. Therefore, the detection of large, experimental, ancient mycobacterial DNA fragments is a suitable approach for paleomicrobiological studies.
\end{abstract}

Keywords: Ancient DNA, DNA degradation, Bacterial DNA, Eukaryotic DNA, Mycobacterium, Real-time PCR

\section{Findings} Introduction

The seminal demonstration that nuclear DNA could be cloned from a 2,400-year-old Egyptian mummy [1] founded molecular paleontology and paleomicrobiology $[2,3]$. However, the cumulative experience over the past few decades indicates that the detection of ancient DNA (aDNA) could be limited by DNA degradation

\footnotetext{
* Correspondence: michel.drancourt@univmed.fr

'URMITE, UM63, CNRS 7278, IRD 198, Inserm 1095, Aix-Marseille Université, 27 boulevard Jean Moulin, Marseille 13005, France

${ }^{2}$ Unité des Rickettsies, Faculté de Médecine, 27 Boulevard Jean Moulin, Marseille Cedex 05 13385, France
}

influenced by $\mathrm{pH}$ and humidity of the burial site. Heat, ultraviolet rays and oxidative agents are also proposed to contribute to the alteration of the chemical nature of nucleic acid bases and the degradation of DNA in buried human and animal remains [4-8]. Based on theoretical models of DNA degradation $[4,9,10]$, some authors have questioned the long-term stability of DNA and suspected that some paleomicrobiological detections may have resulted from the contamination of samples with modern DNA [5,11]. Studies have demonstrated aDNA to be degraded into $<150$-bp nuclear and $<400$-bp mitochondrial fragments [12,13]. Experimental models of DNA degradation have used purified DNA [14-16]

\section{() Biomed Central}

(c) 2012 Nguyen-Hieu et al.; licensee BioMed Central Ltd. This is an Open Access article distributed under the terms of the Creative Commons Attribution License (http://creativecommons.org/licenses/by/2.0), which permits unrestricted use, distribution, and reproduction in any medium, provided the original work is properly cited. 
because few studies have assessed the degradation of DNA within cells [17]. Moreover, these early studies used eukaryotic DNA. Indeed, the potential degradation of prokaryotic aDNA was only extrapolated from the data obtained from eukaryotic aDNA without experimental validation. Some authors have proposed, however, that in ancient, buried specimens, bacterial DNA may be more resistant to decay over time than human DNA $[18,19]$. In this study, we evaluated experimental DNA decay in both eukaryotic and prokaryotic cells.

\section{Dry heat degradation of murine macrophage cell line $J 774$ DNA and M. smegmatis DNA}

One-hour incubation of M. smegmatis and J774 cells at $90^{\circ} \mathrm{C}$ resulted in cell death as indicated by the absence of subculture. All blank control PCR reactions were negative. The cycle threshold $(\mathrm{Ct})$ values of PCR-amplified fragments from J774. DNA and M. smegmatis negative control DNA (without heat exposure) varied from 26-33 for J774 cell $r p b 2$ fragments and 24-29 for M. smegmatis rpoB fragments. For test samples exposed to $90^{\circ} \mathrm{C}$ dry heat for intervals ranging from 1 to $48 \mathrm{~h}$, the $\mathrm{Ct}$ values of PCR-amplified fragments were observed to increase relative to those of controls at each amplicon size tested. Furthermore, for each dry heat exposure time, the Ct values of the shorter 146-149-bp fragments were lower than those of the longer 746-747-bp fragments (Additional file 1: Table S1). During the 4- to 24-h dry heat exposures, J774 cell DNA degraded into 597-bp fragments. After $48 \mathrm{~h}$ of exposure, however, only 450-bp rpb2 fragments of 7774 cell DNA could be amplified. In contrast, 746-bp rpoB fragments of $M$. smegmatis DNA could be amplified even after $48 \mathrm{~h}$ of dry heat exposure (Figure 1). The DNA degradation of J774 cells was more rapid than that of M. smegmatis through $1-48$ - hour exposure to dry heat (ANOVA test, $\mathrm{p}<10^{-3}$, Additional file 2: Table S2).

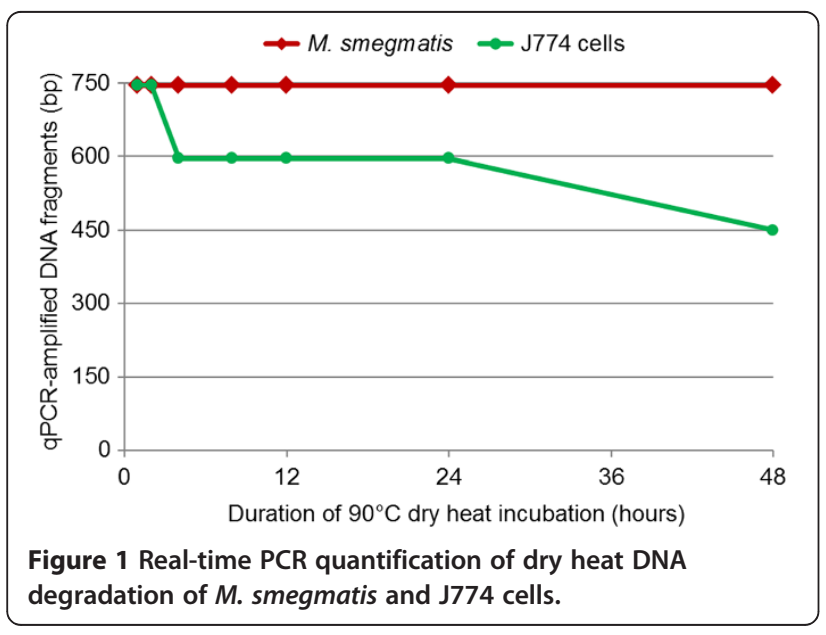

Dry heat degradation of M. smegmatis-infected $\mathrm{J774}$ cell DNA

In the experiments utilizing intracellular bacteria, all blank controls were negative. M. smegmatis-infected J774 cells not exposed to dry heat served as negative controls, and the Ct values of PCR-amplified DNA varied from 23 - 30 for 5774 fragments and $27-28$ for M. smegmatis fragments. After exposure to $90^{\circ} \mathrm{C}$ dry heat for durations ranging from 1 to $48 \mathrm{~h}$, the $\mathrm{Ct}$ values of test samples were observed to increase relative to those of controls for each amplicon size. Additionally, for each dry heat exposure time, the Ct values of the shorter 146-149-bp fragments were lower than those of the longer 746-747-bp fragments (Additional file 3: Table S3). After $48 \mathrm{~h}$ of dry heat exposure, only the 450bp fragments of infected J774 cell DNA could be amplified. In contrast, the 746-bp fragments of intracellular M. smegmatis DNA could be amplified following the same 48-h dry heat exposure (Figure 2). The DNA degradation of the infected-J774 cells was more rapid than that of intracellular M. smegmatis through $2-12$ - hour and 48 - hour exposure to dry heat (ANOVA test, $\mathrm{p}<0.05$, Additional file 2: Table S2). There was no statistically significant difference in the degradation of $\mathrm{J774}$ cell DNA, between M. smegmatis-infected and noninfected cells (ANOVA test, $\mathrm{p}>0.05$, Additional file 2: Table S3).

The data presented in this manuscript can be interpreted as both authentic and biologically relevant. All blank controls used in our PCR-based experiments were negative. Additionally, the control cells not exposed to dry heat yielded the expected results. Macrophages and mycobacteria were exposed to dry heat in parallel, and the rpoB gene of mycobacteria was assessed in parallel with its homolog, the $r p b 2$ gene of murine macrophages. Reproducible results were observed across experiments performed in triplicate.

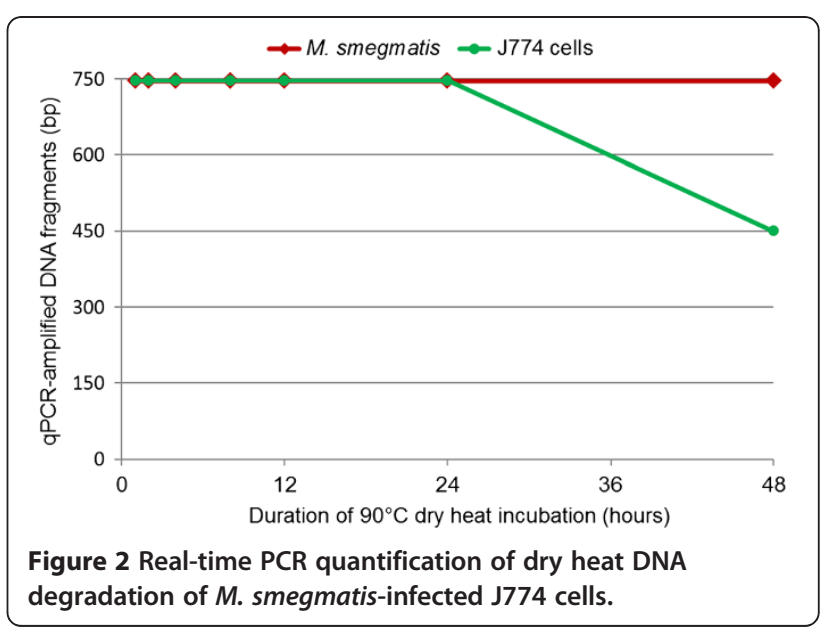


The dry heat used in this study has been used previously to assess experimental degradation of purified DNA [16,17] and is the most common environmental agent that may cause DNA damage in dead cells. Thus, our experiments utilizing dry heat exposure mimic an accelerated natural DNA degradation process. Furthermore, in this study, dry heat was applied to cellular DNA rather than purified DNA. We verified that these conditions killed mycobacteria. However, the experimental design of the study did not allow us to rule out the hypothesis that viable non-culturable mycobacteria persisted into infected macrophages [20], possibly interfering with macrophage DNA degradation. Additionally, all previously published experiments have used agarose gel electrophoresis to monitor DNA degradation [14-17]. This method of evaluation is imprecise, as it relies on the visual observation of smears and only provides estimates as to the extent of DNA degradation. In our study, we used real-time PCR in combination with TaqMan ${ }^{\circledR}$ fluorescent probes to accurately monitor the size of PCR-amplifiable fragments of mycobacterial and eukaryotic DNA following exposure to heat stress. $M$. smegmatis was chosen because it has a lipid-rich cell wall similar to that of Mycobacterium tuberculosis, a pathogen previously investigated in paleomicrobiological studies [3,18]. Furthermore, M. smegmatis-infected J774 cells were used as an experimental model with which to assess DNA degradation of obligate intracellular bacteria. This model of particular interest because Rickettsia prowazekii and Mycobacterium leprae, which are obligate intracellular bacteria, have been detected in ancient specimens [21-24]. Our studies assessing experimental and comparative degradation of cellular DNA in both bacteria and eukaryotic cells are the first in the literature.

Several criteria have been published to authenticate aDNA-based data $[2,11]$. These include the absence of a positive control, negativity of negative controls, sequencing all PCR amplicons, amplification and sequencing of a second target, originality of the ancient sequences and reproducibility of results in at least two independent laboratories. The data presented here are consistent with previously published paleomicrobiological observations. DNA fragments exceeding 350-bp have been PCRamplified from several ancient bacterial pathogens, including M. tuberculosis and M. leprae, from a number of ancient, buried individuals (Figure 3, Additional file 4: Table S4). Bone, mummified tissues (e.g. mummy, skull, lung, pleura, and rib) and dental pulp are often used for these types of paleomicrobiological investigations (Figure 3), although aDNA is more easily extracted from soft tissues than from calcified ones. The data reported herein cannot be extrapolated to other bacteria, nevertheless DNA fragments larger than 250-bp from infectious agents have been successfully PCR-amplified from ancient dental pulp specimens [24-31]. This finding supports the hypothesis that dental pulp is a good source of genetic material for DNA-based paleomicrobiological studies [32]. The published data indicate that the average eukaryotic DNA fragment size in these experiments does not correlate with the age of ancient specimens (Figure 3), suggesting that DNA degradation occurs relatively soon after cell death $[4,12]$. Indeed, 250-bp average fragments have been sequenced from both a 30,000year-old permafrost sediment [33] as well as a 40,000year-old cave bear bone [34]. Interestingly, most large DNA fragments recovered from permafrost sediment are comprised of mostly bacterial DNA, supporting the idea that bacterial DNA was better preserved than eukaryotic DNA in ancient specimens.

\section{Conclusions}

Field observations, along with the experimental data presented here, suggest that mycobacterial DNA is more resistant than eukaryotic DNA to taphonomic degradation. Bacterial DNA fragmentation could be offset by DNA repair activities $[35,36]$. The measurement of carbon dioxide release from bacteria embedded in permafrost for 500,000 years found that bacterial metabolic activity ensured survival and DNA repair capacity [37]. Additionally, thick cell walls, like those of mycobacteria, could protect bacterial DNA from certain degrading agents $[18,19]$. The dogma that ancient bacterial DNA is fragmented to an extent where only targets shorter than 200-bp can be detected [38] is not supported by either the experimental data or the high-throughput pyrosequencing observations. Large bacterial DNA fragments can be detected from ancient buried specimens without enzymatic reparation [39].

\section{Methods \\ Culture of murine macrophage cell line $\mathrm{J774}$ and M. smegmatis}

The murine macrophage J774 (ATCC TIB 67) cells were cultured in GIBCO $^{\circledR}$ 1X DMEM culture medium (Invitrogen, Carlsbad, USA) supplemented with $10 \%$ heatdecomplemented fetal calf serum (Seromed, Strasbourg, France) and $1 \%$ glutamine (Seromed) at $37^{\circ} \mathrm{C}$ with $5 \%$ $\mathrm{CO}_{2}$ for 3 days. M. smegmatis mc2 (ATCC 700084) was cultured in trypticase-soy-casein broth (European Pharmacopia IV, Strasbourg, France) supplemented with $0.5 \%$ Tween 80 (European Pharmacopia IV) at $37^{\circ} \mathrm{C}$ for 10 days. For the co-culture experiment, $1.8 \mathrm{~mL}$ of a $10^{6}$ mycobacteria $/ \mathrm{mL}$ suspension were incubated with $15 \mathrm{~mL}$ of a $10^{5} \mathrm{~J} 774$ cells $/ \mathrm{mL}$ suspension at $37^{\circ} \mathrm{C}$ under $5 \% \mathrm{CO}_{2}$ atmosphere for $4 \mathrm{~h}$. The infected J774 cell monolayer was then washed two times with $15 \mathrm{~mL}$ sterile phosphate buffered saline (PBS) before $15 \mathrm{~mL}$ fresh culture medium supplemented with $1 \%$ streptomycin 
(Panpharma, Fougères, France) was added for $2 \mathrm{~h}$, eliminating any extracellular mycobacteria [40]. The infected-cell monolayer was then washed two times with $15 \mathrm{~mL}$ sterile PBS before $15 \mathrm{~mL}$ of fresh culture medium was added. The monolayer was incubated at $37^{\circ} \mathrm{C}$ with $5 \% \mathrm{CO}_{2}$ for $24 \mathrm{~h}$. Infection of the $\mathrm{J774}$ cell layer was monitored by Ziehl-Neelsen staining. The viability of $M$. smegmatis mycobacteria and J774 cells after one-hour incubation at $90^{\circ} \mathrm{C}$ was assessed by subculture as described above.

\section{Experimental degradation of DNA}

$200 \mu \mathrm{L}$ suspensions of $2.10^{4} \mathrm{~J} 774$ cells $/ \mathrm{mL}, 2.10^{5} \mathrm{M}$. smegmatis/mL or $2.10^{4}$ M. smegmatis-infected J774 cells/ 
$\mathrm{mL}$ were incubated in parallel at $90^{\circ} \mathrm{C}$ in a dry heat incubator (Techne Dri-Block ${ }^{\circledR}$, Staffordshire, UK) for 1, 2, 4, $8,12,24$ or $48 \mathrm{~h}$. All experiments were conducted in triplicate. The cell suspensions not exposed to dry heat were included as negative controls. The DNA was extracted by adding $0.3 \mathrm{~g}$ of $106-\mu \mathrm{m}$ glass beads (Sigma Aldrich, Steinheim, Germany) to $200 \mu \mathrm{L} J 774$ cells or to M. smegmatis or M. smegmatis-infected J774 cells in $1.5 \mathrm{~mL}$ Eppendorf tubes. The cell suspensions were homogenized in a FastPrep-24 Instrument (MP Biomedicals Europe) 3 times for $20 \mathrm{~s}$ at $4 \mathrm{~m} / \mathrm{s}$ and were then centrifuged at $16,045 \times \mathrm{g}$ for $3 \mathrm{~min}$. DNA extraction was then performed using the QIAamp ${ }^{\circledR}$ DNA Mini kit (Qiagen, Hilden, Germany) following a modified protocol. Briefly, $200 \mu \mathrm{L}$ ATL buffer and $20 \mu \mathrm{L}$ proteinase $\mathrm{K}$ were added to each cell tube. The cell suspensions were vortexed for $15 \mathrm{~s}$ and then incubated at $56^{\circ} \mathrm{C}$ for $45 \mathrm{~min}$. The $420-\mu \mathrm{L}$ supernatant was transferred to a new Eppendorf tube and mixed with $200 \mu \mathrm{L}$ absolute ethanol by vortexing for $15 \mathrm{~s}$. The $620-\mu \mathrm{L}$ mixture was transferred to a NucleoSpin column, and all following steps were conducted according to the QIAamp ${ }^{\circledR}$ DNA Mini Kit protocol. The resulting DNA was diluted with $60 \mu \mathrm{L}$ AE buffer.

\section{Real-time PCR measurements}

Two PCR primer systems were designed using the software Perlprimer version 1.1.6 [41]. The Rpb2.J774mur primer system specifically amplified sequences of different sizes (e.g., 146-bp, 298-bp, 450-bp, 597-bp and 747-bp) of the J774 rpb2 gene (gi|161898209|gb| EF536008.1|), and primer system RpoB.Msmeg amplified sequences of different sizes (149-bp, 298-bp, 444-bp, 599-bp and 746-bp) of the M. smegmatis rpoB gene (gi| 34595742|gb|AY262735.1|). Two fluorescent probes, Rpb2.J774mur-TaqMan and RpoB.Msmeg-TaqMan, were designed to hybridize to the PCR-amplified $r p b 2$ and rрoB fragments, respectively (Figure 4, Additional file 5 : Table S5). Amplifications were performed in Stratagene MX3000P (Agilent Technologies Company, La Jolla, CA, USA) and CFX96" Real-Time Systems (Bio-Rad, Singapore) using $10 \mu \mathrm{L}$ reaction mixture (Quantitech, Qiagen), $2 \mu \mathrm{L}$ sterile water, $2 \mu \mathrm{L}$ Taqman $^{\circledR}$ probe (Applied Biosystems, Villebon-sur-Yvette, France), $0.5 \mu \mathrm{L}$ forward primer $(10 \mu \mathrm{M}), 0.5 \mu \mathrm{L}$ reverse primer $(10 \mu \mathrm{M})$ and $5 \mu \mathrm{L}$ DNA by under the following PCR conditions: 15 -min activation at $95^{\circ} \mathrm{C}$ and 40 cycles of 30-s denaturation at $95^{\circ} \mathrm{C}, 45$-s hybridization at $62^{\circ} \mathrm{C}$ and 90 -s elongation at $72^{\circ} \mathrm{C}$. Ten negative controls (using DNA extracted from cells without $90^{\circ} \mathrm{C}$ dry heat exposure) were included in every batch. Additionally, ten blank controls (PCR-mix with sterile water instead of DNA) were also included. For each test sample, real-time PCR amplification was conducted in triplicate. Cut-offs were

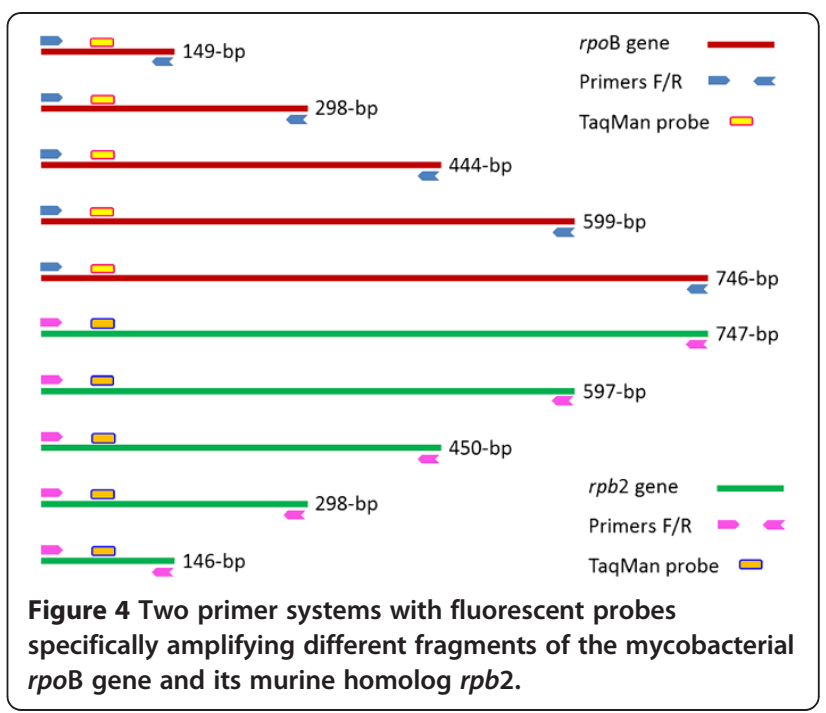

defined empirically; for each amplicon size, a test sample was considered as PCR-negative if its $\mathrm{Ct}$ value was greater than the $\mathrm{Ct}$ value of the negative control plus 12 (4,096 times of decreasing DNA concentration) or if its $\mathrm{Ct}$ value was nil. The $\mathrm{Ct}$ value of the test sample $(\mathrm{Ctx})$ being 41 was delivered for no PCR-amplification or nil $\mathrm{Ct}$ values. PCR-detections of degraded DNA were confirmed as negative when all of three replicates were negative.

\section{Statistical analyses}

The value of the negative control (Ct0) was used as baseline. For each amplicon size, the DNA degradation was calibrated by $\mathrm{Ctx}-\mathrm{Ct} 0$. The ANOVA test was used to compare the means of $(\mathrm{Ctx}-\mathrm{Ct} 0)$ values.

\section{Additional files}

Additional file 1: Table S1. Average $\mathrm{Ct}$ values of $r p b 2$ and $r p o B$ amplified-fragments of $\mathbf{J 7 4}$ cells and M. smegmatis.

Additional file 2: Table S2. ANOVA tests comparing means of (Ctx - Ct0) values.

Additional file 3: Table S3. Average Ct values of rpb2 and rpoB amplified-fragments of M. smegmatis-infected $J 774$ cells.

Additional file 4: Table S4. References of mycobacterial DNA PCR-amplifications from ancient specimens (Figure 3) [1-24].

Additional file 5: Table S5. Primers and $\operatorname{Taqman}^{\circledR}$ probes used for real-time PCR quantification of $\mathbf{J 7 7 4}$ cell rpb2 and M. smegmatis rpoB genes.

\section{Competing interests}

The authors declare that they have no competing interests.

\section{Authors' contributions}

TNH did the experiments, analyzed the data and drafted the manuscript. GA participated in the overall design and finalized the draft of the manuscript. MD designed the study, analyzed the data and finalized the draft of the manuscript. All the authors read and approved the final version of the manuscript. 


\section{Acknowledgements}

This study was supported by Unité de Recherche sur les Maladies Infectieuses et Tropicales Emergentes.

Received: 29 May 2012 Accepted: 12 September 2012

Published: 25 September 2012

\section{References}

1. Paabo S: Molecular cloning of ancient Egyptian mummy DNA. Nature 1985, 314:644-645

2. Drancourt M, Raoult D: Palaeomicrobiology: current issues and perspectives. Nat Rev Microbiol 2005, 3:23-35.

3. Spigelman $M$, Lemma $E$ : The use of the polymerase chain reaction (PCR) to detect mycobacterium tuberculosis in ancient skeletons. Int J Osteoarchaeol 1993, 3:137-143.

4. Lindahl T: Instability and decay of the primary structure of DNA. Nature 1993, 362:709-715.

5. Hofreiter M, Serre D, Poinar HN, Kuch M, Paabo S: Ancient DNA. Nat Rev Genet 2001, 2:353-359.

6. Gilbert MT, Binladen J, Miller W, Wiuf C, Willerslev E, Poinar H, Carlson JE, Leebens-Mack JH, Schuster SC: Recharacterization of ancient DNA miscoding lesions: insights in the era of sequencing-by-synthesis. Nucleic Acids Res 2007, 35:1-10.

7. Hofreiter $M$, Jaenicke $V$, Serre D, Haeseler AA, Paabo S: DNA sequences from multiple amplifications reveal artifacts induced by cytosine deamination in ancient DNA. Nucleic Acids Res 2001, 29:4793-4799.

8. Willerslev E, Cooper A: Ancient DNA. Proc Biol Sci 2005, 272:3-16.

9. Poinar HN, Hoss M, Bada JL, Paabo S: Amino acid racemization and the preservation of ancient DNA. Science 1996, 272:864-866.

10. Smith Cl, Chamberlain AT, Riley MS, Cooper A, Stringer CB, Collins MJ: Neanderthal DNA. Not just old but old and cold? Nature 2001, 410:771-772.

11. Cooper A, Poinar HN: Ancient DNA: do it right or not at all. Science 2000 , 289:1139.

12. Millar CD, Huynen L, Subramanian S, Mohandesan E, Lambert DM: New developments in ancient genomics. Trends Ecol Evol 2008, 23:386-393.

13. Paabo S: Ancient DNA: extraction, characterization, molecular cloning, and enzymatic amplification. Proc Natl Acad Sci USA 1989, 86:1939-1943.

14. Cataldo F: DNA degradation with ozone. Int J Biol Macromol 2006 38:248-254.

15. Tanaka K, Okamoto A: Degradation of DNA by bisulfite treatment Bioorgan Med Chem Lett 2007, 17:1912-1915.

16. Zhang $\mathrm{L}, \mathrm{Wu} \mathrm{Q}$ : Single gene retrieval from thermally degraded DNA. J Biosci 2005, 30:599-604

17. Dobberstein RC, Huppertz J, von Wurmb-Schwark N, Ritz-Timme S: Degradation of biomolecules in artificially and naturally aged teeth: implications for age estimation based on aspartic acid racemization and DNA analysis. Forensic Sci Int 2008, 179:181-191.

18. Donoghue HD, Spigelman M, Greenblatt CL, Lev-Maor G, Bar-Gal GK, Matheson C, Vernon K, Nerlich AG, Zink AR: Tuberculosis: from prehistory to Robert Koch, as revealed by ancient DNA. Lancet Infect Dis 2004, 4:584-592.

19. Zink AR, Reischl U, Wolf $H$, Nerlich AG: Molecular analysis of ancient microbial infections. FEMS Microbiol Lett 2002, 213:141-147.

20. Shleeva M, Mukamolova GV, Young M, Williams HD, Kaprelyants AS: Formation of 'non-culturable' cells of mycobacterium smegmatis in stationary phase in response to growth under suboptimal conditions and their Rpf-mediated resuscitation. Microbiology 2004, 150:1687-1697.

21. Donoghue HD, Marcsik A, Matheson C, Vernon K, Nuorala E, Molto JE, Greenblatt CL, Spigelman M: Co-infection of mycobacterium tuberculosis and mycobacterium leprae in human archaeological samples: a possible explanation for the historical decline of leprosy. Proc Biol Sci 2005 272:389-394.

22. Haas CJ, Zink A, Palfi G, Szeimies U, Nerlich AG: Detection of leprosy in ancient human skeletal remains by molecular identification of mycobacterium leprae. Am J Clin Pathol 2000, 114:428-436.

23. Nguyen-Hieu T, Aboudharam G, Signoli M, Rigeade C, Drancourt M, Raoult D: Evidence of a louse-borne outbreak involving typhus in Douai, 1710-1712 during the war of Spanish succession. PLoS One 2010, 5:e15405.
24. Raoult D, Dutour O, Houhamdi L, Jankauskas R, Fournier PE, Ardagna Y Drancourt M, Signoli M, La VD, Macia Y, Aboudharam G: Evidence for louse-transmitted diseases in soldiers of Napoleon's grand army in Vilnius. J Infect Dis 2006, 193:112-120.

25. Bianucci R, Rahalison L, Massa ER, Peluso A, Ferroglio E, Signoli M: Technical note: a rapid diagnostic test detects plague in ancient human remains: an example of the interaction between archeological and biological approaches (Southeastern France, 16th-18th centuries). Am J Phys Anthropol 2008, 136:361-367.

26. Drancourt M, Signoli M, Dang LV, Bizot B, Roux V, Tzortzis S, Raoult D: Yersinia pestis orientalis in remains of ancient plague patients. Emerg Infect Dis 2007, 13:332-333.

27. Drancourt M, Aboudharam G, Signoli M, Dutour O, Raoult D: Detection of 400-year-old yersinia pestis DNA in human dental pulp: an approach to the diagnosis of ancient septicemia. Proc Natl Acad Sci USA 1998, 95:12637-12640.

28. Drancourt M, Roux V, Dang LV, Tran-Hung L, Castex D, Chenal-Francisque V, Ogata H, Fournier PE, Crubezy E, Raoult D: Genotyping, orientalis-like yersinia pestis, and plague pandemics. Emerg Infect Dis 2004, 10:1585-1592.

29. Drancourt M, Tran-Hung L, Courtin J, Lumley H, Raoult D: Bartonella quintana in a 4000-year-old human tooth. J Infect Dis 2005, 191:607-611.

30. La VD, Clavel B, Lepetz S, Aboudharam G, Raoult D, Drancourt M: Molecular detection of bartonella henselae DNA in the dental pulp of 800-year-old French cats. Clin Infect Dis 2004, 39:1391-1394.

31. Papagrigorakis MJ, Yapijakis C, Synodinos PN, Baziotopoulou-Valavani E: DNA examination of ancient dental pulp incriminates typhoid fever as a probable cause of the plague of Athens. Int J Infect Dis 2006, 10:206-214.

32. Nguyen-Hieu T, Aboudharam G, Drancourt M: Mini review: dental pulp as a source for paleomicrobiology. Bull Int Assoc Paleodont 2011, 5:48-54.

33. D'Costa VM, King CE, Kalan L, Morar M, Sung WW, Schwarz C, Froese D, Zazula G, Calmels F, Debruyne R, Golding GB, Poinar HN, Wright GD: Antibiotic resistance is ancient. Nature 2011, 477:457-461.

34. Noonan JP, Hofreiter M, Smith D, Priest JR, Rohland N, Rabeder G, Krause J, Detter JC, Paabo S, Rubin EM: Genomic sequencing of pleistocene cave bears. Science 2005, 309:597-599.

35. Friedberg EC, Wagner R, Radman M: Specialized DNA polymerases, cellular survival, and the genesis of mutations. Science 2002, 296:1627-1630.

36. Radman M: Fidelity and infidelity. Nature 2001, 413:115.

37. Johnson SS, Hebsgaard MB, Christensen TR, Mastepanov M, Nielsen R, Munch K, Brand T, Gilbert MT, Zuber MT, Bunce M, Ronn R, Gilichinsky D, Froese D, Willerslev E: Ancient bacteria show evidence of DNA repair. Proc Natl Acad Sci USA 2007, 104:14401-14405.

38. Paabo S, Poinar H, Serre D, Jaenicke-Despres V, Hebler J, Rohland N, Kuch M Krause J, Vigilant L, Hofreiter M: Genetic analyses from ancient DNA. Annu Rev Genet 2004, 38:645-679.

39. Mitchell D, Willerslev E, Hansen A: Damage and repair of ancient DNA. Mutat Res 2005, 571:265-276.

40. Ren H, Liu J: AsnB is involved in natural resistance of mycobacterium smegmatis to multiple drugs. Antimicrob Agents Ch 2006, 50:250-255.

41. Marshall OJ: PerlPrimer: cross-platform, graphical primer design for standard, bisulphite and real-time PCR. Bioinformatics 2004, 20:2471-2472.

doi:10.1186/1756-0500-5-528

Cite this article as: Nguyen-Hieu et al:: Heat degradation of eukaryotic and bacterial DNA: an experimental model for paleomicrobiology. BMC Research Notes 2012 5:528. 